\title{
Talking about the Influence of Financing Methods and Financing Tools on the Long-term Smooth Development of China's Real Estate Market
}

\author{
Gao Lizhong \\ International Business School, Shaanxi Normal University \\ Xi'an 710062, Shaanxi, China
}

\begin{abstract}
The real estate market, one of pillar industries in China, has a long development cycle and large investment along with capital intensive. Only by ensuring the stability of the real estate market, solving its financial problems and protecting the company from phased cash pressure at the development stage, can sustainable development of the real estate market be guaranteed. This paper analyzed the basic theories and related research of domestic and foreign scholars in the real estate market. It proposes that new financing tools and channels play roles in the long-term stable development of the real estate market and in realizing the "soft landing" of the real estate market economy.
\end{abstract}

Keywords-Real estate market; Financing; Financing methods; Financing tools; Long-term stable development

\section{INTRODUCTION}

The development of real estate enterprises is inseparable from effective financing. Effective financing is critical to the development of real estate companies. The development of the real estate market is also inextricably linked. As of 2018, the financing channels of most real estate companies in China still rely only on bank credit. Current domestic economic depression, The pressure on the real estate industry is even more severe. According to the law of economic development, The decline of the real estate market is bound to affect the entire financial system. Initiating systemic financial risks, Eventually counteracting the entire economic society, It has an irreversible negative impact on the macro economy.

\section{THEORETICAL BASIS AND RELATED RESEARCH ON REAL ESTATE ENTERPRISE FINANCING}

At present, domestic and foreign real estate companies conduct financing activities through the following methods:

(1)Investment through fixed capital; the company uses the profits earned in the business process for project funds.

(2)Financing through equity transactions: the profits of the real estate enterprise shareholders who give up their ownership or shares in the enterprise, and use the proceeds for the project.

(3)Financing through bank commercial loans: the company raises money by borrowing from banks.
(4)Financing through securities or listing means, that is means of financing the securities market through the way of listing of enterprises, or securitization of real estate commodities, and financing through securities trading.

(5)Financing is carried out through trust funds: a trust company is established, and the trust company manages the project funds.

(6)Financing through private lending: the company borrows from private capital and assumes the actual interest rate of borrowing above the bank interest rate.

(7)Financing through corporate and government cooperation, that is, securitization of PPP assets. The PPP model is a major innovation in the public service delivery mechanism. The government adopts a competitive approach to select social capital with investment and operational management capabilities. The two parties conclude the contract in accordance with the principle of equal consultation. Defining responsibility and rights, providing public services by social capital, The government pays the corresponding consideration to social capital based on the results of public service performance evaluation, Ensure that social capital receives reasonable income.

\section{A. Research on real estate financing at home and abroad}

1) Research on real estate financing theory

According to the foreign enterprise financing theory, it can be divided into three categories: 1. Early enterprise financing structure theory school; 2. Modern enterprise financing structure theory school; 3 . Financing structure theory system.

Damien Maguire (1994) believes that the sources of funds in the real estate market mainly include equity financing and debt financing. The main way of debt financing is through commercial loans through banks.

Liu Biao(2005) proposed that the commercial loan financing mechanism dominated during the transition period, but this model will be replaced by a regulatory financing mechanism in the future.

Wu Shuyi (2008) believes that the reasons for the current situation of China's real estate financial market are: In the past two decades, China's real estate market has received high 
demand, but the real estate industry development and financing channels are limited to commercial bank loans. This channel limits the means of financing real estate companies and limits the development of the entire financial market.

\section{2) Research on real estate financing tools}

John A. Mullaney (1997) predicted the securitization of the real estate market in the future. He believes that real estate securitization will be the mainstream way of real estate financing in the future.

Zhang Liya (2014) pointed out that a single commercial loan will bring many inconveniences and restrictions to the development of real estate enterprises. Therefore, the real estate industry needs to enrich financing channels and actively explore new financing methods. External financing is more suitable for long-term development of real estate enterprises than internal financing.

Tang Lei (2015) puts forward the legal issues of China's real estate market: only perfecting the relevant laws in the real estate field, and improving the policy rules is the guarantee for the rapid, healthy and stable development of the real estate market.

\section{3) Research on new real estate financing}

Steve Bergsman (2012) pointed out that real estate securitization will be affected by stock market volatility, and even counteract the entire stock market, so it is necessary to explore new financing methods. The current popularity of trust is not as good as securitization, but in the future, the real estate trust fund will become the dominant way.

Pan Guojin (2010) research shows that domestic real estate enterprises should learn from the experience of international financial securitization, and at the same time, adapt to local conditions and explore financing methods and combinations that are in line with their own development.

Zhang Xiaoman (2014) also expressed this view in his research: The traditional commercial loan method has high requirements for corporate credit and debt, and the way of equity financing and securitization can provide enterprises with a new way of thinking and financing.

Martin Hoesli (2012) believes that trust-based real estate financing can reduce corporate risks, enjoy preferential policies, and benefit more clients while facilitating financing.

Ge Ying (2010) conducted a related study on REITs and found that: The reasons why REITs can grow rapidly and rapidly are: The first is the policy dividend, which is mainly reflected in the tax advantages; The second is flexibility. In response to different policy rules and economic conditions at different times, trust companies can tailor different trust products to meet their needs; Finally, liquidity, liquidity makes its audience more and reduces risk.

\section{4) Proposal of combined financing methods}

$\mathrm{Wu}$ Guojun (2015) pointed out that a single financing tool has huge limitations and cannot meet the needs of enterprise development. Combined financing tools can foster strengths and circumvent weaknesses, more comprehensive and practical solutions to corporate needs, and at the same time more conducive to the development of China's real estate market.

$\mathrm{Xu}$ Yeye (2014) proposed that the Internet model is the trend of the times, and the financial system needs to actively explore cooperation with the Internet industry. From equipment to channels, we should have Internet thinking, and make technological innovation, thinking innovation, channel innovation, and method innovation. Real estate companies should also join the Internet to explore cooperation and find a new financing model of their own.

\section{PROBLEMS AND SUGGESTIONS}

According to the research of scholars at home and abroad, most scholars mainly focus on:

Research on corporate financing structure and real estate enterprise financing theory and methods, There are currently few areas involving new financing instruments and financing portfolios. Therefore, while perfecting the theoretical system, we fill the gaps in the industry. Starting from the real estate financing tools and other aspects, we actively explore the impact of new financing tools on real estate enterprises, and finally improve the current theoretical research.

\section{A. Enrich financing means and use new financing tools efficiently}

According to the actual situation of China's real estate market, we found that the channels of domestic real estate enterprises are too single, and they are almost exclusively financed through a single channel of bank loans. Although the single use of the banking channel can reduce the risk of corporate financing, it will also cause the bank to bear the operational risks and market risks of the entire real estate industry, resulting in macro risks of the entire real estate market and the entire economy, which is not conducive to long-term stable economic development. Some scholars in China have also studied new financing methods, but the research is currently limited to the theoretical level. It is still unclear whether the actual problems can be solved. Moreover, domestic real estate enterprises are not paying much attention to new financing methods and financing tools. Therefore, the efficient use of new financing tools will become a crucial means for real estate companies to cope with development advantages and respond to risks in the future. At present, real estate asset securitization, trust, and internet plus can improve the current situation and promote the stable development of the real estate market and enterprises.

Although real estate securitization will bring higher risks, it can expand the financing of real estate enterprises, make the financing channels more transparent, and improve the investment and financing income. At the same time, the way of real estate securitization is more diverse. For example, real estate enterprise securitization, real estate asset securitization, backdoor listing, etc., which makes real estate companies have 
more operational space and operation methods. Moreover, some real estate companies in China today have used similar methods, and their rationality and effectiveness have been considered to make them have reference value.

The way of real estate trust can reduce financing risks while shortening financing time. Bring more small and medium-sized investors into the real estate market, so that the benefits will expand while diversifying financial risks. Moreover, the professional trust company established by the Real Estate Trust will professionally manage its trust products. Its risk control department will control its risks, which is more conducive to the steady development of enterprises and industries.

Real estate internet plus. Can rely on new Internet financing channels, gathering social idle funds, integrate institutional funding, So as to solve the problem of financing difficulties for small and medium-sized real estate enterprises, at the same time, internet plus provides big data support for real estate enterprises and industries, which is beneficial to the overall layout of real estate enterprises, thereby reducing risks and contributing to the steady development of enterprises and industries.

The combination of financing methods can help real estate companies to expand the amount of financing and reduce financing risks. At the same time, in the process of financing, real estate enterprises can give full play to the advantages of various financing methods, and use the form of combination to avoid adverse effects and be more proactive. For example, the early implementation of the property-benefit trust financing model of real estate enterprises is conducive to the transition to the investment fund model when the time is ripe, which can speed up the financing speed and financing scope of enterprises, while reducing the cost of future changes. Moreover, more and more real estate companies use a combination of commercial loans and real estate securitization to achieve financing. In the case of a stable domestic economic environment, the combination of debt financing and securitization financing can help solve the debt problem of real estate enterprises. In any case, combined financing methods provide more diverse financing channels for real estate companies, as a company, in order to ensure the long-term and stable development of itself and the industry, it is necessary to analyze various combinations according to their own circumstances and select an appropriate combination.

\section{B. Increase government supervision and increase the scope of supervision}

China's current real estate laws and regulations are not perfect, and laws and regulations are improved, sound policy rules can ensure the stable development of the real estate market. At the same time, how to control the new and innovative means of the real estate market in recent years is also a problem that the government needs to solve in time. In response to the financing methods of the new real estate market, the government should make progress together with real estate companies. There are currently some lack of legal supervision and legislative work on real estate trust, how to supervise and control P2P Internet + real estate financial products, and how to better regulate illegal financing in the real estate market, It is necessary for the government to attach importance to it and introduce relevant regulations as soon as possible. To prevent real estate financial market risks, the only way to ensure the stable development of the industry, so that the emerging areas do not become "extra-flight enclaves. "At the same time, it should be noted that the stability of the real estate financial market is the key to China's ability to cope with financial systemic risks. It is extremely important to increase government supervision and achieve comprehensive and advancing with the times.

\section{Increase government participation and reduce industry risks}

Taking the PPP government and social capital cooperation, the essence of PPP is the sharing of benefits between the government and enterprises, risk sharing, and full cooperation. For the government, the PPP cooperation model opens up infrastructure and public service projects to social capital, broadens the financing channels of the real estate market, and improves the level of economic development and accelerates economic transformation, using government endorsements to flexibly use various types of financial instruments such as fund investment, bank loans, and bond issuance. Promoting the establishment of a diversified and sustainable PPP project funding guarantee mechanism to reduce risks and promote stable development of the industry.

\section{SUMMARY}

According to the analysis and research of the financing methods of China's real estate market, we can see that the rational use of real estate financing theory is the premise of the normal and reasonable development of the real estate market; Efficient and rational use of new real estate financing means can enhance the development prospects of the real estate industry and increase the internal driving force of the industry; Increasing government supervision and participation can reduce and reduce the financial risks in the real estate market, which will help the long-term economy to grow at a good and fast rate, so that the short-term economy will reach a stable "soft landing." 


\section{REFERENCES}

[1] Modigliani F, Miller M H. THE COST OF CAPITAL, CORPORATION FINANCE AND THE THEORY OF 1NVESTMIENT[J] .American Economic Review, 1958, 48 (3):261-297.

[2] Damien Maguire, Andrew Ax cells Real Estate Finance, Germany and the UK[J].Journal of Property Finance, Vo1.5 Iss: 1,2004:pp.29-40.

[3] John A. Mullet'. REITs: Building Profits With Real Estate Investment Trusts[M].John Wiley and Sons, 2007.

[4] Durand. Trends and Problems of Measurement in Conference on Research on Business Finance. New York: National Bureau of Economic Research,2010:57-79.

[5] Steve

Bergsman.REITs\&Rates.WWW.nareit.tom, September/October,2006.

[6] Keith Smith and David Shulman,1976."The Performance of Equity Real Estate Investment Trusts." Financial Analysts Journal, SeptemberOctober 1976,61-66.

[7] Wu Guojun. Research on China's real estate financing under the condition of stable monetary policy [J]. China Science and Technology Information, 2015.01.

[8] Zhang Xiaoman. Problems and Countermeasures of Financial Management of Real Estate Enterprises[J]. Finance and Economics: Academic Edition, 2014 (19).

[9] Xu Yeye. Risks and Avoiding Strategies of Real Estate Enterprise Financing. Enterprise Reform and Management, 2014 (21).

[10] Liu Biao, Corporate Finance Issues and Development Strategies [[J]. North China Finance, 2008 (11).

[11] Wu Shuyi. Problems and Development Strategies of Real Estate Finance in China [J]. North China Finance, 2008 (O1).

[12] Tang Lei. China's Real Estate Financial Risk and Prevention[J]. Industrial Economy,2015(2):62-64.

[13] Zhang Liya. Analysis of Commercial Real Estate Financing Trend under the Background of Monetary Restriction[J].Commercial Modernization,2014(9):252-253.

[14] Ge Ying. US Commercial Real Estate Financing and Its Impact on the Economy. Shanghai Finance, 2010 (3): 60-62. 